\title{
The carB Gene of Escherichia coli BL21(DE3) is Associated with Nematicidal Activity against the Root-Knot Nematode Meloidogyne javanica
}

\author{
Yanfei Xia ${ }^{1,2,3, *}$, Shen $\mathrm{Li}^{3}$, Guohui Xu ${ }^{1}$, Shanshan Xie ${ }^{2}{ }^{\circledR}$, Xueting Liu ${ }^{3}$, Xiaomin $\operatorname{Lin}^{3}$, Huijun $\mathrm{Wu}^{2, *}$ \\ and Xuewen Gao ${ }^{2}$ \\ 1 Department of Forensic Medicine, Affiliated Hospital of Guilin Medical University, 15 Lequn Road, \\ Guilin 541001, Guangxi, China; ghxu2004@163.com \\ 2 Department of Plant Pathology, College of Plant Protection, Nanjing Agricultural University, 1 Weigang Road, \\ Nanjing 210095, Jiangsu, China; xssflora871216@126.com (S.X.); gaoxw@njau.edu.cn (X.G.) \\ 3 Department of Plant Protection, College of Horticulture and Plant Protection, \\ Henan University of Science and Technology, 263 Kaiyuan Avenue, Luoyang 471023, Henan, China; \\ 18438615966@163.com (S.L.); lytz1503678@163.com (X.L.); xiaomlin@163.com (X.L.) \\ * Correspondence: xyfyanfei@163.com (Y.X.); hjwu@njau.edu.cn (H.W.); \\ Tel.: +86-773-2816-299 (Y.X.); +86-25-8439-5268 (H.W.)
}

check for

updates

Citation: Xia, Y.; Li, S.; Xu, G.; Xie, S.; Liu, X.; Lin, X.; Wu, H.; Gao, X. The carB Gene of Escherichia coli BL21(DE3) is Associated with Nematicidal Activity against the Root-Knot Nematode Meloidogyne javanica. Pathogens 2021, 10, 222. https://doi.org/10.3390/ pathogens10020222

Academic Editor: Giovanni Bubici Received: 31 December 2020

Accepted: 16 February 2021

Published: 18 February 2021

Publisher's Note: MDPI stays neutral with regard to jurisdictional claims in published maps and institutional affiliations.

Copyright: (C) 2021 by the authors Licensee MDPI, Basel, Switzerland. This article is an open access article distributed under the terms and conditions of the Creative Commons Attribution (CC BY) license (https:// creativecommons.org/licenses/by/ $4.0 /)$.

\begin{abstract}
Biological nematicides have been widely used to lower the losses generated by phytoparasitic nematodes. The purpose of this study was to evaluate the nematicidal effects of Escherichia coli BL21(DE3) against Meloidogyne javanica and to identify nematicide-related genes. Culture filtrates of BL21(DE3) caused juvenile mortality and inhibited egg hatching in a dose-dependent manner. In the greenhouse, treatment of tomato seedlings with BL21(DE3) culture filtrates at 50 and 100\% concentrations not only reduced the amount of $M$. javanica egg masses and galls, but improved plant root and shoot fresh weight. Culture filtrate analysis indicated that the nematicidal active ingredients of strain BL21(DE3) were non-proteinaceous, heat and cold resistant, sensitive to $\mathrm{pH}$ and volatile. To identify the genes associated with nematicidal activity, a BL21(DE3) library of 5000 mutants was produced using Tn 5 transposase insertion. The culture filtrate of the MB12 mutant showed no nematicidal activity after $72 \mathrm{~h}$ of treatment and thermal asymmetrical interlaced PCR demonstrated that the $\operatorname{carB}$ gene was disrupted. Nematicidal activity was restored when the $\mathrm{pH}$ of the MB12 culture filtrate was adjusted to the original $\mathrm{pH}$ value (4.15) or following MB12 complementation with the $c a r B$ gene, confirming a role for $c a r B$ in mediating $\mathrm{pH}$ value and nematicidal activity. The outcomes of this pilot study indicate that BL21(DE3) is a potential microorganism for the continuable biological control of root-knot nematode in tomato and that carB affects the nematicidal activity of BL21(DE3) by modulating the $\mathrm{pH}$ environment.
\end{abstract}

Keywords: biocontrol; Meloidogyne javanica; carB gene; Escherichia coli BL21(DE3); culture filtrate

\section{Introduction}

The root-knot nematode (RKN) Meloidogyne spp. is an important plant pathogen. It infects numerous crops, and leads to annual yield damages of about USD 400 million worldwide [1]. Chemical nematicides represent the conventional nematode management strategy due to their broad spectrum of targets and high efficacy [2]. However, some nematicides have been withdrawn or even banned, due to their latent poisonous effects on human and environmental safety [3]. Therefore, the search for novel potential candidates for the biocontrol of plant-parasitic nematodes to maintain economic and social stability has become increasingly important.

Numerous biocontrol bacteria (e.g., Pasteuria spp., Bacillus spp., Pseudomonas spp.,) have been proposed as sustainable alternatives to control phytoparasitic nematodes [4-7]. Pasteuria penetrans has been widely reported to directly parasitize plant-parasitic nematodes, 
especially Meloidogyne species [8,9]. Metabolic by-products from Pseudomonas fluorescens, such as 2,4-diacetylphloroglucinol (2,4-DAPG), have presented potential in killing cyst nematode juveniles $[10,11]$. Bacillus nematocida B16 possesses nematicidal activity against Panagrellus redivius as well as Bursaphelenchus xylophilus, using a Trojan horse mechanism $[12,13]$. Extracellular bacterial enzymes, which are critically important during nematode infection, rapidly decompose the cuticle of nematodes [14]. Moreover, B. thuringiensis (Bt) produces the well-known Cry protein, which displays specific toxic activity against nematodes and insects [15]. In addition, induced systemic resistance (ISR) is triggered by plant growth-promoting rhizobacteria (PGPR) [16,17].

Escherichia coli is the most widely studied prokaryotic model organism. The majority of $E$. coli strains are sackless, but a few serum types can result in critical illness in their hosts, such as enteropathegenic, enteroinvasive, enterohemorrhagic and enterotoxigenic E. coli. The E. coli strain OP50 is the famous nutrient material for Caenorhabditis elegans in the lab [18]. Recently, enterohemorrhagic E. coli O157:H7 was found to cause the death of $C$. elegans via either fast-kill or slow-kill phenotypes [19,20]. M. javanica acts as a provisional reservoir for E. coli strain TG1 under laboratory conditions [21]. The BL21(DE3) E. coli strain is widely used for the manufacture of recombinant proteins under the control of integrated T7-polymerase in biotechnology and microbiology [22]. However, to our knowledge, BL21(DE3) controlling plant-parasitic nematodes has not been described in the literature. We serendipitously observed that culture filtrates of BL21(DE3) showed strong nematicidal activity against RKNs and, to understand the nematicidal mechanism better, we studied this in more detail. Random DNA insertion into bacterial chromosomes is an important technique, which has been used to identify new genes, novel functions of known genes and to study protein functions. Recently, the Tn5-based transposon system has been successfully applied to mutagenize various bacteria to study genome evolution and genetic diseases [23-25]. The purpose of this research was to assess the nematicidal effects of E. coli strain BL21(DE3) culture filtrate against the RKN M. javanica and to identify potential nematicide-related genes using $\operatorname{Tn} 5$ transposon mutagenesis.

\section{Results}

\subsection{In Vitro Nematicidal Activity}

The percentage of nematode mortality differed with concentrations of culture filtrates of BL21(DE3) and exposure (Figure 1). The percentage mortality of second-stage juveniles (J2s) exposed to highly concentrated culture filtrates was markedly greater than that of those exposed to low-concentration culture filtrates and controls after $12 \mathrm{~h}$ of incubation. At this time point, $100 \%$ supernatants caused $100 \% \mathrm{~J} 2$ mortality. A $25 \%$ concentration of culture filtrate also led to $100 \%$ mortality of J2s following $36 \mathrm{~h}$ of incubation. Sterile distilled water and uninoculated Landy medium used as a control had no influence on the M. javanica juveniles examined. Generally, dead nematodes sank to the bottom, whereas those treated with BL21(DE3) culture filtrates were increasingly suspended in the culture filtrate as the treatment time increased. Furthermore, the internal organs of dead juveniles shrank and separated from the body cuticle and many bubbles were observed (Figure 2). No morphological changes were observed for J2s in the controls.

Disparate concentrations of BL21(DE3) supernatants remarkably suppressed the hatching of $M$. javanica eggs. However, $\mathrm{J} 2$ emergence was inversely proportional to the supernatant concentration. Exposure to increasing concentrations of BL21(DE3) culture filtrate increased the inhibition of egg mass hatching and inhibition rates ranged from $87.53 \%$ to 98.83\% after two weeks of incubation (Table 1). 


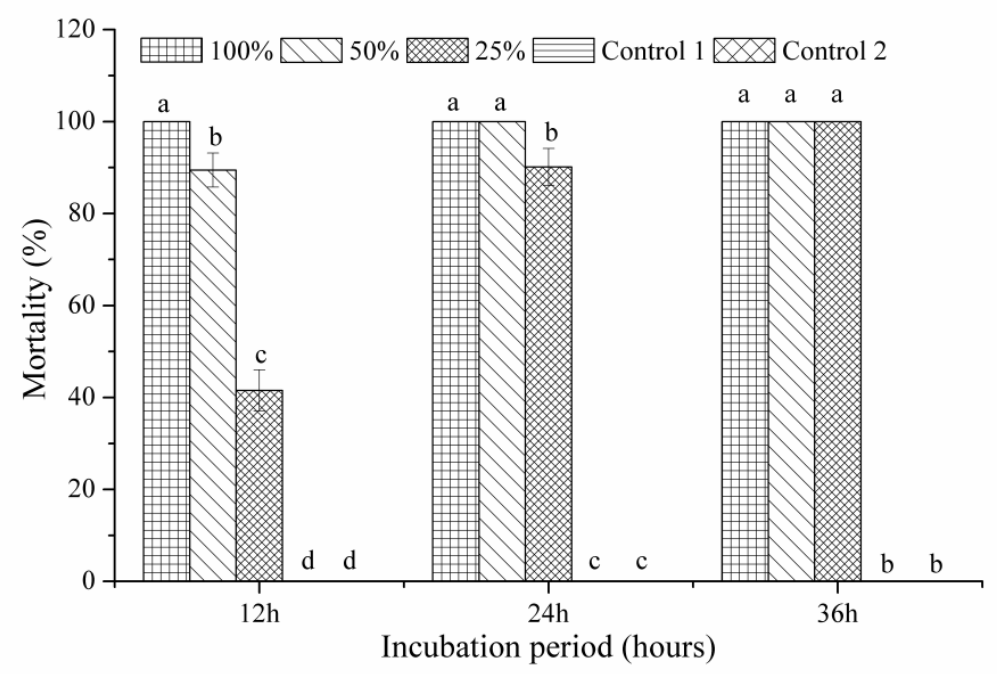

Figure 1. In vitro effect of different concentrations of Escherichia coli BL21(DE3) culture filtrates on Meloidogyne javanica mortality. Control 1: uninoculated Landy medium; Control 2: sterile distilled water. Data are means of one independent test with three replicates $\pm \mathrm{SE}$. Same letters demonstrate no statistical differences at $p \leq 0.05$ by Fisher's least significant difference test. Three independent tests produced similar outcomes; therefore, one result is shown.

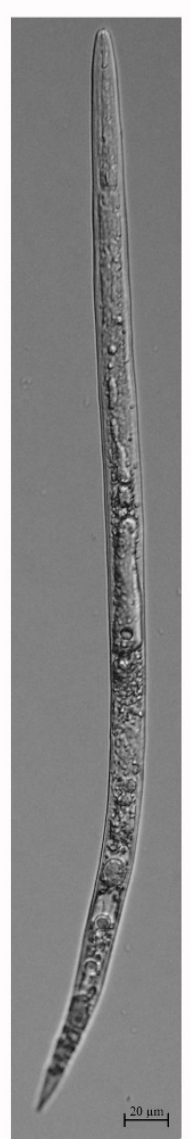

Control

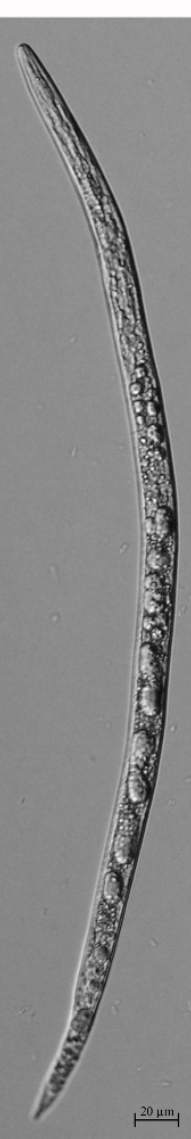

$12 \mathrm{~h}$

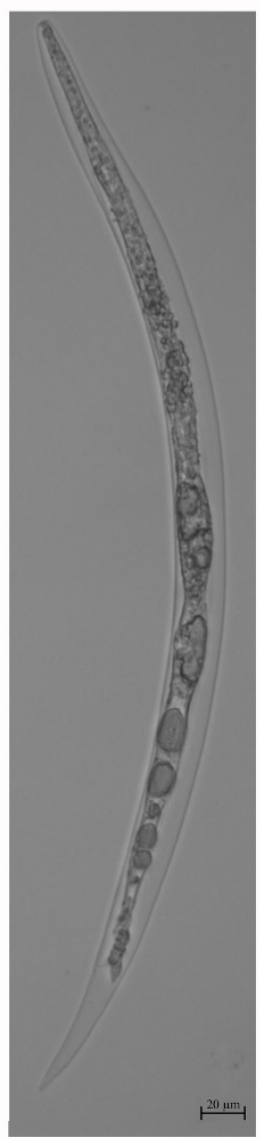

$24 \mathrm{~h}$

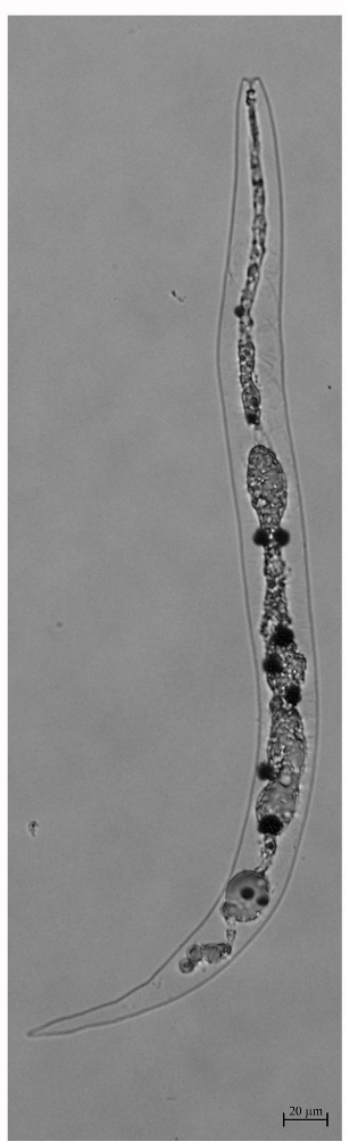

$36 \mathrm{~h}$

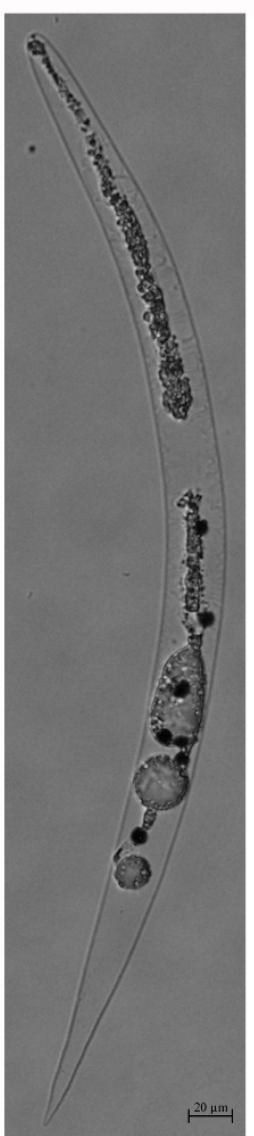

$48 \mathrm{~h}$

Figure 2. Morphological phenotypes of Meloidogyne javanica second-stage juveniles treated with undiluted supernatants (100\% concentration) at different time points. 
Table 1. Effect of different concentrations of Escherichia coli BL21(DE3) on the cumulative hatching frequency of egg masses of Meloidogyne javanica after 14 days of incubation in vitro.

\begin{tabular}{ccc}
\hline Treatment & No. of Juveniles Hatched & Hatching Inhibition Rate (\%) \\
\hline $100 \%$ & $28.67 \pm 7.37 \mathrm{a}$ & 98.83 \\
$50 \%$ & $133.33 \pm 18.61 \mathrm{~b}$ & 94.56 \\
$25 \%$ & $305.67 \pm 34.39 \mathrm{c}$ & 87.53 \\
Control & $2453 \pm 121.20 \mathrm{~d}$ & \\
\hline
\end{tabular}

Control, sterile distilled water. Values are means \pm SD. In a column, data followed by different superscript letters are significantly different at $p \leq 0.05$ by Fisher's least significant difference test. Three replicates were performed per treatment. Three independent tests produced similar outcomes; therefore, one result is shown.

\subsection{Nematicidal Active Stability}

Following protease hydrolysis, the BL21(DE3) supernatants showed the same $100 \%$ nematicidal activity as the supernatants without protease treatment, suggesting that the nematicidal components are not proteins.

BL21(DE3) culture filtrates were subjected to cold or heat to examine the stability of the nematicidal metabolites. Despite these treatments, the extracts retained $100 \%$ nematicidal activity after an exposure period of $12 \mathrm{~h}$, demonstrating that the active components are highly stable.

Following $12 \mathrm{~h}$ of incubation, BL21(DE3) culture filtrates with a broad $\mathrm{pH}$ range of 3.5-5.0 showed the same nematicidal efficacy as the original filtrates (Control 1), whereas those with a $\mathrm{pH}$ of 5.5, 6.0, 7.0 and 8.0 showed either reduced or no antagonistic activity (Figure 3). With an increase in exposure time, culture filtrates with a $\mathrm{pH}$ of 5.5 also resulted in $100 \% \mathrm{~J} 2$ mortality at $36 \mathrm{~h}$, whereas those with a $\mathrm{pH}$ of $6.0,7.0$ and 8.0 still displayed no nematicidal activity. Sterile controls at $\mathrm{pH} 3.0$ and 12.0 did not affect nematicidal activity. The outcomes indicate that the bioactive compounds in BL21(DE3) culture filtrates are stable in an acidic environment.

The collected extracts caused $100 \%$ mortality of J2s after $12 \mathrm{~h}$ of incubation, but the residues had no nematicidal activity after $48 \mathrm{~h}$ of incubation, suggesting that the nematicidal bioactive substances were volatile.

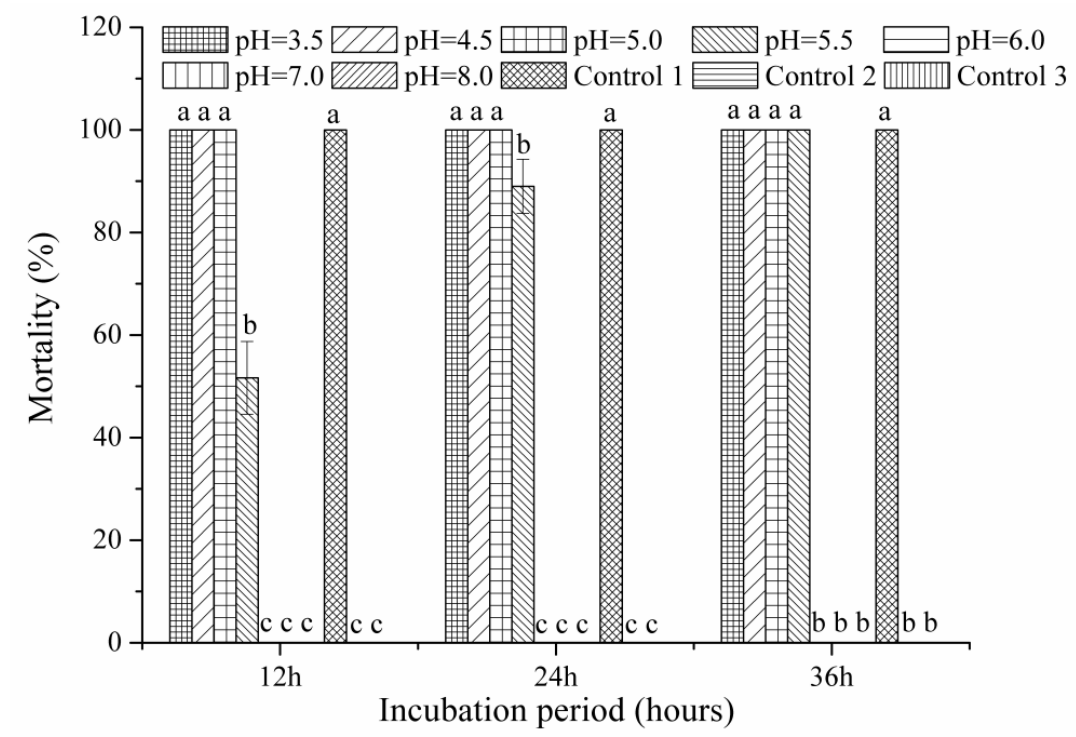

Figure 3. In vitro effect of $\mathrm{pH}$-modified culture filtrates from BL21(DE3) on Meloidogyne javanica mortality. Control 1: original culture filtrate (4.15); Control 2: uninoculated Landy medium; Control 3: sterile distilled water. Data are means of one independent test with three replicates \pm SE. Different letters indicate statistical differences at $p \leq 0.05$ by Fisher's least significant difference test. Three independent tests produced similar outcomes; therefore, one result is shown. 


\subsection{Glasshouse Experiments}

Further studies were conducted to determine the effect of a soil drench of filtrates of strain BL21(DE3) against RKNs in tomato plants grown under greenhouse conditions. Following inoculation with $100 \%$ and $50 \%$ concentrations of BL21(DE3) culture filtrates, the root and shoot fresh weights increased by $39.61 \%$ and $28.70 \%$ (100\% test), or by $33.57 \%$ and $19.22 \%$ (50\% test), respectively (Figure $4 \mathrm{a}, \mathrm{c}, \mathrm{d})$. The number of egg masses and root knots per plant decreased by $27.85 \%$ and $32.68 \%$ (100\% test), or $22.55 \%$ and $25.22 \%$ (50\% test), respectively (Figure $4 \mathrm{~b}$ ). Nevertheless, the $25 \%$ test only resulted in a significant difference in disease density and no remarkable difference in the biomass of tomato plants when compared to control plants $(p \leq 0.05)$.
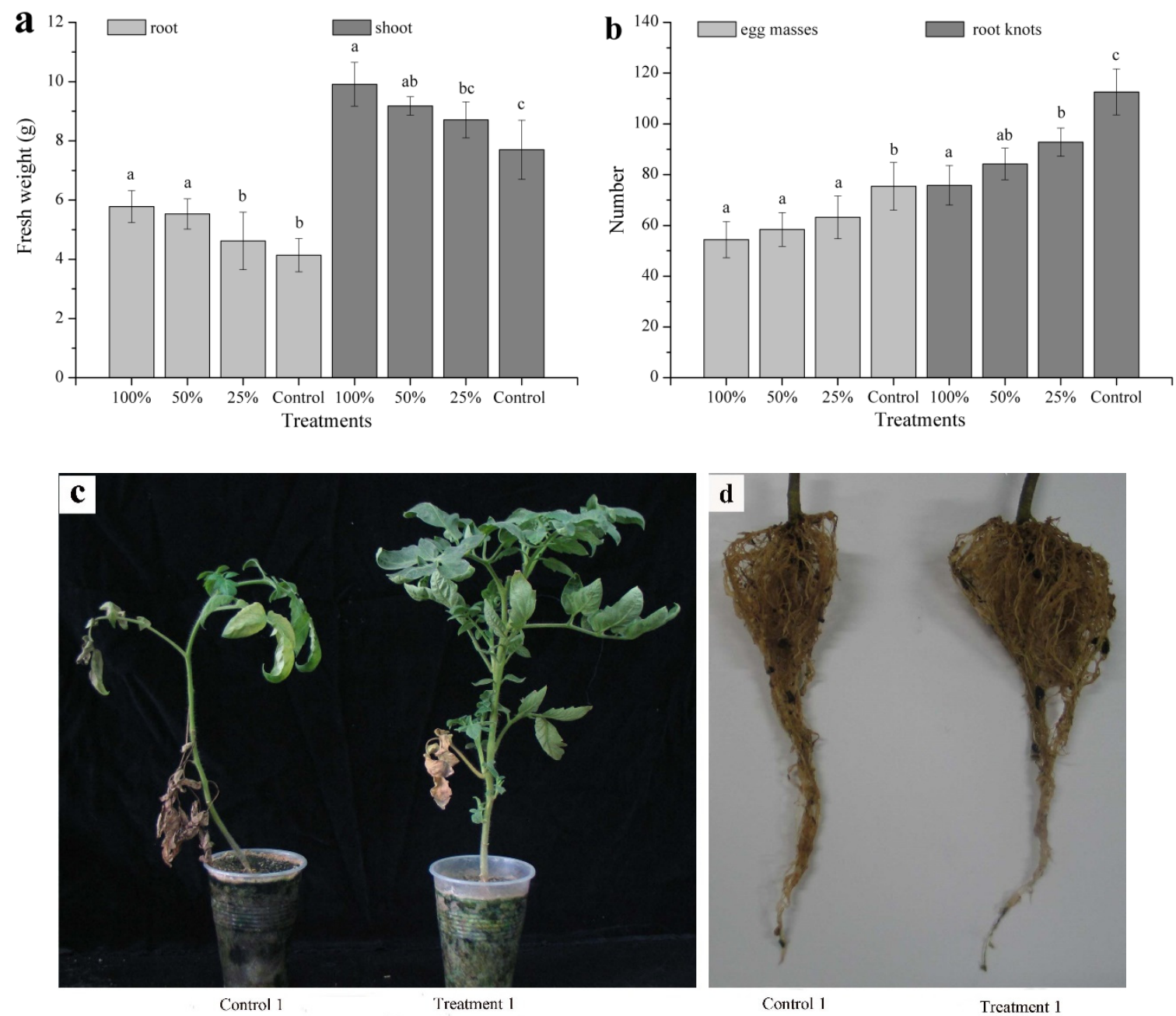

Figure 4. Effects of BL21(DE3) filtrate treatment on (a) tomato plant biomass, (b) Meloidogyne javanica root-knot and egg mass densities, (c) disease symptoms of shoot and (d) disease symptoms of root. Control: sterile distilled water. Control 1: tap water. Treatment 1: 100\% concentration of BL21(DE3) culture filtrates. Values are the means \pm SD from five replicates. For each parameter (root, shoot, egg masses and root knots), columns followed by the same letter are not significantly different at $p \leq 0.05$ by Fisher's least significant difference test.

\subsection{Genetics of Nematicidal Activity}

To identify and characterize potential genes associated with nematocidal activity, a transposon library containing 5000 BL21(DE) mutants was constructed by Tn5 random insertion and the library transformants were screened for nematicidal activity. One transformant, termed MB12, which produced a filtrate $\mathrm{pH}$ of 6.1 , showed no nematicidal activity against M. javanica juveniles after $72 \mathrm{~h}$ of incubation. 
The position of the Tn5 transposon in MB12 mutants was identified by thermal asymmetrical interlaced PCR. The PCR products were attached to a pUC18 vector and transformed into E. coli $\mathrm{DH} 5 \alpha$. The positive transformants were verified by PCR and sequenced. The insertion in MB12 was located in $\operatorname{car} B$, which encodes a carbamoyl phosphate synthase (CPS) large subunit harboring two ATP-binding sites. The CPS enzyme catalyzes the conversion of bicarbonate, glutamine and two molecules of $\mathrm{Mg}^{2+} \mathrm{ATP}$ into carbamoyl phosphate (CP) [26].

The pColdcarB plasmid was constructed to confirm whether the $c a r B$ gene was liable for the observed antagonistic effect of MB12. The MB12 mutant was transformed with pColdcarB and positive transformants were determined by PCR combined with a double digestion technique. The transformant named MB12-1, with a filtrate $\mathrm{pH}$ of 4.2 , showed the same nematicidal efficacy as that foreseen in the wild-type strain BL21(DE3), demonstrating that the $c a r B$ gene of $E$. coli BL21(DE3) mediated nematicidal activity. Furthermore, supernatants of MB12 adjusted to $\mathrm{pH} 4.15$ also led to $100 \%$ mortality of J2s after $12 \mathrm{~h}$ of exposure.

\section{Discussion}

Many studies have reported that plant-parasitic nematodes can be controlled through active substances generated by bacteria during the fermenting process $[7,11,13,17,27-30]$. Specifically, several pathogenic E. coli isolates have been assessed for their ability to kill the free-living nematode C. elegans $[19,20]$. However, non-pathogenic E. coli that are antagonistic against $M$. javanica have not been documented. This study is the first to demonstrate nematicidal activity against the plant-parasitic nematode $M$. javanica by E. coli BL21(DE3) culture filtrates. Additionally, BL21 was also antagonistic to M. incognita, M. arenaria, M. hapla and Heterodera glycines in a similar way to that observed against $M$. javanica, but was not toxic to Aphelenchoides besseyi, Ditylenchus destructor and Bursaphelenchus xylophilus (data not shown). Similar results were reported by Mendoza et al. (2008), who demonstrated the effects of metabolic by-products of Bacillus firmus on M. incognita, Radopholus similis and D. dispaci [28]. The compound 2, 4-DAPG generated by P. fluorescens was not toxic to selected nematode [31]. At present, the mechanism for this disparity is not documented, but we speculate that the differences might reside in differences in the activity, detoxification, tolerance and exclusion capabilities between the different genera. Furthermore, supernatants of the virulent E. coli strain K88 and avirulent strains OP50, Top10, JM109, DH5 $\alpha$ and Rosetta were also toxic to $M$. javanica, similar to the antagonistic effect on $M$. javanica presented in this research, and all these strains showed a similar nematicidal activity (data not shown). The findings suggest that the nematicidal active components are present in supernatants of these isolates. Indeed, some bioactive substances, such as lytic enzymes, Cry toxins, 2-hydroxypropanoic acid, plantazolicin, 2, 4-DAPG and sphingosine isolated from bacterial culture filtrates, are well known to antagonize plant-parasitic nematodes [11,15,32-34]. Analysis of BL21(DE3) culture filtrates indicated that the bioactive compounds were non-proteinaceous, heat and cold resistant and volatile, similar to the active components produced by B. subtilis strain OKB105 [29]. The data here clearly indicate that $\mathrm{pH}$ affected the antagonistic nematicidal activity of these compounds. Similarly, sphingosine produced by B. cereus strain S2 displayed nematicidal potential in the $\mathrm{pH}$ range from 2.0 to 8.0 [33]. Additionally, BL21(DE3) nematicidal compounds destroyed the internal structure of $\mathrm{J} 2 \mathrm{~s}$ and numerous large vesicles were observed in J2s treated with BL21(DE3) supernatants. Similar symptoms of internal nematode organ injury have been documented following treatment with B. cereus X5, Camellia seedcake extracts, 5-Aminolevulinic acid (ALA) or sphingosine [30,33,35,36]. Further research is required to identify the nematicidal substances, using analytical techniques such as liquid chromatography-mass spectrometry (LC-MS), gas chromatography-mass spectrometry (GC-MS) and nuclear magnetic resonance (NMR), and to elucidate the nematicidal mechanism of BL21(DE3).

On account of the growth-promoting capability and the nematicidal potential, numerous bacteria (e.g., Bacillus spp., Pseudomonas spp.) can be used to manage plant-parasitic 
nematodes via various mechanisms of action [7,37]. However, to our knowledge, no reports exist concerning the use of BL21(DE3) as a biocontrol agent. The results obtained under greenhouse conditions demonstrated that BL21(DE3) filtrates increased the growth parameters of tomato seedlings (root and shoot fresh weight) and decreased the harm degree generated by M. javanica (amount of egg masses and root knots) when used at a concentration of 50 or $100 \%$, whereas treatment with a $25 \%$ BL21(DE3) filtrate concentration was ineffective on tomato growth compared to the control. These data therefore indicate that a 50\% BL21(DE3) filtrate concentration is optimal to control M. javanica in a greenhouse environment; nevertheless, further research is necessary to test the biocontrol effect of BL21(DE3) against RKNs in field trials and to demonstrate the mechanism of action against nematodes in vivo.

Random mutagenesis systems based on in vivo transposon insertion into the genome are extensively applied to mining functional genes of microorganisms [38,39]. In this research, the BL21(DE3) mutant library was obtained using the Tn5 transposon and the mutant nematicidal capability was assessed to identify nematicide-related genes. The MB12 mutant showed a lack of nematicidal activity and 14 mutants delayed the onset of injury to the internal organs of dead J2 nematodes (data not shown). The Tn 5 transposon of MB12 was located within the $c a r B$ gene, which encodes a large subunit of CPS. Carbamoyl phosphate is a vital small molecule that powers cell metabolism and can donate a carbamyl group within numerous well-known biosynthetic pathways, including the arginine/urea, pyrimidine and antibiotic synthesis pathways [40,41]. Besides being involved in biosynthetic pathways, $c a r B$ has been recently reported to possess novel functions: disruption of $c a r B$ in Xanthomonas citri subsp. citri caused pathogenic loss and an inability to induce a hypersensitive reaction (HR) in non-host plants, but also led to reduced swimming ability and biofilm formation [42,43]. The carB gene of Toxoplasma gondii, which results in birth defects and destructive toxoplasmic cephalitis in immunocompromised humans, has an important role in growth and virulence [44]. The findings are the first to demonstrate that the $c a r B$ gene of BL21(DE3) affects nematicidal capability. The cheB2, $m u c D$ and purL genes are also involved in nematicidal activity $[29,45,46]$. Loss of carB function in the MB12 mutant affected the synthesis of CPS, the amino acid sequence of which differs from those nematicidal proteases of bacteria $[14,47,48]$. This finding, in combination with the properties of supernatants obtained in this study, demonstrates that the large CPS subunit was not responsible for nematicidal activity. Culture filtrates of the complemented MB12-1 strain displayed the same nematicidal capability as the original BL21(DE3) supernatants, but also a similar $\mathrm{pH}$ value. The nematicidal activity of MB12 was restored following adjustment of the $\mathrm{pH}$ to the control $\mathrm{pH}$ value of 4.15 . These results, in association with the $\mathrm{pH}$ stability of supernatants demonstrated here, indicate that BL21(DE3) nematicidal activity is indirectly affected by $c a r B$ via a change in $\mathrm{pH}$. A similar study has reported that $c a r B$ of $X$. citri subsp. citri affected pathogenicity and HR in non-hosts by regulating hrp gene expression [42]. Furthermore, the purL gene had been shown to mediate the antagonistic potential of $B$. subtilus strain OKB105 via the metabolic intermediates of purine biosynthesis [29]. The data here indicate that $c a r B$ regulates the nematicidal ability of BL21(DE3) by modulating the $\mathrm{pH}$ environment. However, the mechanism remains indistinct and requires further study.

In conclusion, this study is the first report that E. coli strain BL21(DE3) is a potential microbe for the management of RKNs in tomato. We also demonstrated that the loss of $\operatorname{car} B$ function led to the loss of nematicidal activity of BL21(DE3) by altering the $\mathrm{pH}$ environment.

\section{Materials and Methods}

\subsection{Strains and Plasmids}

The bacterial strains and plasmids used for this study are listed in Table 2. E. coli strain DH5 $\alpha$ acted as the host for all plasmids. Luria broth (LB) was used for the growth of all E. coli strains and BL21(DE3) mutants at $37^{\circ} \mathrm{C}$. Landy medium was used to ferment 
E. coli BL21(DE3) and mutants [49]. All of the strains were stored at $-80{ }^{\circ} \mathrm{C}$. A small piece of ice carrying the strain was taken from the stores by using a sterilized toothpick, streaked on LB medium and then cultured at $37^{\circ} \mathrm{C}$. After $24 \mathrm{~h}$ of incubation, the single colony, whose phenotype showed no difference from the previous strain, was transferred to liquid medium for further research. Where necessary, media were supplemented with the corresponding antibiotics (ampicillin at $100 \mathrm{ug} \mathrm{mL}^{-1}$ and kanamycin at $50 \mu \mathrm{g} \mathrm{mL} \mathrm{m}^{-1}$ ).

Table 2. Bacterial strains and plasmids used in this study.

\begin{tabular}{|c|c|c|}
\hline Material & Relevant Genotype or Characteristics * & Source or Reference \\
\hline \multicolumn{3}{|l|}{ Strains } \\
\hline \multicolumn{3}{|l|}{ Escherichia coli } \\
\hline $\mathrm{DH} 5 \alpha$ & $F^{-}, \varphi 80 \mathrm{~d} / \mathrm{lacZ} \Delta \mathrm{M} 15, \Delta($ lacZYA-argF $) \mathrm{U} 169, \mathrm{deoR}$ & This lab \\
\hline BL21(DE3) & $F^{-}$, omp $T, h s d S B(r B-m B-)$, gal dcm(DE3) & This lab \\
\hline MB12 & Mutant of BL21(DE3), carB::Tn5; $\mathrm{Km}^{\mathrm{r}}$ & This study \\
\hline MB12-1 & Complementation of MB12 mutant with expression vector pColdcarB; $\mathrm{Ap}^{\mathrm{r}}, \mathrm{Km}^{\mathrm{r}}$ & This study \\
\hline \multicolumn{3}{|c|}{ 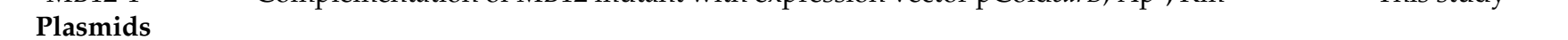 } \\
\hline pUC18 & E. coli clone vector; lacZ; Ap ${ }^{r}$ & This lab \\
\hline pColdII & $\operatorname{csp} \mathrm{A}$ promoter-based expression vector; $\mathrm{Ap}^{\mathrm{r}}$ & This lab \\
\hline pUCcarB & pUC18 derivative carrying $\operatorname{carB} ; \mathrm{Ap}^{\mathrm{r}}$ & This study \\
\hline pColdcarB & pCold II derivative carrying $\operatorname{car} B ; \operatorname{csp} A$ promoter-based expression vector; $\mathrm{Ap}^{\mathrm{r}}$ & This study \\
\hline
\end{tabular}

${ }^{*}$ Resistance marker: $\mathrm{Ap}^{\mathrm{r}}$, ampicillin resistance; $\mathrm{Km}^{\mathrm{r}}$, kanamycin resistance.

\subsection{Preparation of Meloidogyne javanica}

M. javanica was originally obtained from Hainan province, China and has been cultivated continually in tomato plants. The egg masses were gathered from roots of glasshousegrown tomato plants and the second-stage juveniles (J2s) were separated by the Baermann funnel technique [50]. The collected eggs and nematodes were separately sterilized using $1 \% \mathrm{NaClO}$ for five minutes and washed three times with sterile distilled water before use.

\subsection{Antagonism of Strain BL21(DE3) against M. javanica In Vivo}

The BL21(DE3) strain and mutants were grown in Landy medium on a rotary shaker (200 rpm) at $37^{\circ} \mathrm{C}$ for $48 \mathrm{~h}$. Culture filtrates were collected at $12,000 \mathrm{rpm}$ for $15 \mathrm{~min}$ at $4{ }^{\circ} \mathrm{C}$ and disinfected using $0.22 \mu \mathrm{m}$ bacterial filters; these were denoted as original supernatants ( $100 \%$ concentration) that were successively attenuated with sterile distilled water to 50 and $25 \%$ concentrations to observe nematicidal activity following the described procedure [29]. The number of dead nematodes was recorded using a light microscope at 12, 24, 36 and $48 \mathrm{~h}$. Uninoculated Landy medium and sterile distilled water were used as controls. Tests were performed three times with three replicates per trial.

To assess the ovicidal action of BL21(DE3), egg masses were prepared following a revised method [51]. Briefly, six disinfected egg masses of the same size were stochastically picked using sterile forceps and placed into a $6 \mathrm{~cm}$ diameter watch glass with $1 \mathrm{~mL}$ $100 \%, 50 \%$ or $25 \%$ concentrations of BL21(DE3) supernatant. Sterile distilled water was used as a control. All treatments were placed in a $25{ }^{\circ} \mathrm{C}$ incubator for two weeks. The incubation solutions were changed for fresh ones every two days. The solution containing the nematodes was transferred to a counting dish and the J2 number was recorded under a dissecting microscope. Tests were performed three times with three replicates per treatment.

\subsection{Different Treatments of BL21(DE3) Supernatants}

The BL21(DE3) filtrates were treated with trypsin or proteinase $\mathrm{K}\left(20 \mathrm{mg} \mathrm{mL}^{-1}\right)$ at $37^{\circ} \mathrm{C}$ for thirty minutes. Thereafter, the nematicidal capability of the supernatants was observed according to the method above. The cold and heat resistance of the bacterial metabolites was based on previously described procedures $[27,29]$. Culture filtrates were separately incubated at $4{ }^{\circ} \mathrm{C},-25^{\circ} \mathrm{C}$ and $-80^{\circ} \mathrm{C}$ for $10,20,30,60$ or 90 days; at $100{ }^{\circ} \mathrm{C}$ for 10,20 or $30 \mathrm{~min}$; or at $121^{\circ} \mathrm{C}$ for 10,15 or $20 \mathrm{~min}$ in an autoclave and were successively examined for nematicidal capability according to the method above. For testing $\mathrm{pH}$ stability 
of BL21(DE3) filtrates, supernatants were calibrated at $\mathrm{pH} 3.5,4.5,5.0,5.5,6.0,7.0$ or 8.0 and were examined for nematicidal activity. The original supernatants ( $\mathrm{pH} 4.15)$ and sterile distilled water with $\mathrm{pH} 3.0$ and 12.0 were used as controls. To assess the volatility of the nematicidal principles, $100 \mathrm{~mL}$ supernatants were evaporated to dryness at $60{ }^{\circ} \mathrm{C}$ using a rotary evaporator. Obtained distillations and residues from the initial filtrates were diluted to the original volume $(100 \mathrm{~mL})$ and were evaluated for nematicidal capability.

All the above experiments were repeated three times with three replicates per treatment.

\subsection{Antagonism of Strain BL21(DE3) against M. javanica In Vivo}

Since strain BL21(DE3) led to a high fatality rate of J2s and inhibited the hatching of egg masses, it was selected to further evaluate its biocontrol potential in a pot test. Tomato seeds (Solanum lycopersicum cv. Sufen) were disinfected with $1 \% \mathrm{NaClO}$ for 5 min and washed a few times with distilled water. The soil used in these trials consisted of a 1:1 $(v / v)$ mixture of sterilized sand and silt loam. Treated seeds were grown in a tray and, 7 days after sprouting, an individual seedling was cultivated in a $10 \mathrm{~cm}$ diameter plastic pot. At 40 days after transplanting, $25 \mathrm{~mL}$ supernatants were poured onto the root system of each plant using a soil drench. Tap water served as a control treatment. After $24 \mathrm{~h}, 1000$ newly hatched J2s per tomato were injected into a $3 \mathrm{~cm}$ deep hole. The test was performed thrice, and each treatment consisted of five replicates, which were randomly put in a glasshouse. These tomatoes needed watering daily and manuring weekly. The tests ended 50 days after inoculation and the fresh weight of the roots and shoots was measured. The number of egg masses and galls per plant was also recorded.

\subsection{DNA Manipulation and Transformation}

DNA ligases and restriction enzymes were applied according to the manufacturer's instructions (TaKaRa, Japan). Kits for isolating and purifying DNA were purchased from Axygen Scientific Inc. (USA). E. coli strain DH5 $\alpha$ was transformed as described [52]. The specific primers are listed in Table 3.

Table 3. Oligonucleotide DNA primers used in this study.

\begin{tabular}{|c|c|c|}
\hline Primers & Sequence (5'-3'; Restriction Sites Underlined if Present) & Use of Primers \\
\hline carB-F & GGATCCATGCCAAAACGTACAGATAT (BamHI) & \multirow{2}{*}{ carB gene amplification } \\
\hline carB-R & AAGCTTTTATTTGATCTGTGCGTGCA (HindIII) & \\
\hline pColdII-F & ACGCCATATCGCCGAAAGG & \multirow{2}{*}{ carB gene identification } \\
\hline pColdII-R & GGCAGGGATCTTAGATTCTG & \\
\hline SP1 & GTCTTCGGTTTCCGTGTTTCG & Tn5 transposon left flanking sequences \\
\hline DP1 & NGTCGASWGANAWGAA & Pre-amplification \\
\hline SP2 & AAATGGCATCCGGATCTGCATC & Tn5 transposon left flanking sequences \\
\hline DP2 & AGWGNAGWANCAWAGG & Primary amplification \\
\hline SP3 & TACCCTGTGGAACACCTACATCTG & Tn5 transposon left flanking sequences \\
\hline DP3 & CAWCGICNGAIASGAA & Second amplification \\
\hline SP4 & GGTTGTAACACTGGCAGAGCATT & Tn5 transposon right flanking sequences \\
\hline DP4 & TCSTICGNACITWGGA & Pre-amplification \\
\hline SP5 & CGCATCTTCCCGACAACGCAG & Tn5 transposon right flanking sequences \\
\hline DP5 & STTGNTASTNCTNTGC & Primary amplification \\
\hline SP6 & AACTGGTCCACCTACAACAAAG & Tn5 transposon right flanking sequences \\
\hline DP6 & WCAGNTGWTNGTNCTG & Second amplification \\
\hline
\end{tabular}

Nested sequence-specific primers (SPs) SP1, SP2 and SP3 are located at the left border of the Tn5 transposon; SP4, SP5 and SP6 are at the right border of the Tn5 transposon. DP1, DP2, DP3, DP4, DP5 and DP6 are shorter arbitrary degenerate primers (DPs).

The BL21(DE3) mutant library was prepared using the transposase-transposon complex (EZ-Tn5 ${ }^{\mathrm{TM}}<\mathrm{R} 6 \mathrm{~K} \gamma$ ori $/ \mathrm{KAN}-2>\mathrm{Tnp}$ Transposome ${ }^{\mathrm{TM}} \mathrm{kit}$ ) according to the manufacturer's instructions (Epicentre, Madison, WI, USA). Transformation of cells with DNA was performed by electroporation $(1800 \mathrm{~V}, 24 \mu \mathrm{S}, 200 \Omega, 0.1-\mathrm{cm}$ cuvettes). The cells were renatured by incubation at $25^{\circ} \mathrm{C}$ for $5 \mathrm{~min}$ with $200 \mu \mathrm{L} \mathrm{LB}$ liquid medium, then put in a $1.5 \mathrm{~mL}$ centrifuge tube with shaking $(200 \mathrm{rpm})$ at $37^{\circ} \mathrm{C}$ for $1.5 \mathrm{~h}$. The transformants were 
plated on LB plates with $50 \mu \mathrm{g} \mathrm{mL} \mathrm{m}^{-1}$ kanamycin and cultured at $37^{\circ} \mathrm{C}$ for $12 \mathrm{~h}$. Every transformed colony was individually recorded and transferred onto new LB plates with kanamycin for further study. To create a transposon library, 10 individual electrotransformations were carried out as described above. The correspondingly numbered clones were stored in $2.0 \mathrm{~mL}$ centrifuge tubes with $30 \%$ glycerol at $-80{ }^{\circ} \mathrm{C}$. The nematicidal activity of mutants was evaluated according to the method above.

\subsection{Determination of the Transposon Insertion Site}

A fragment flanking the Tn5 transposon was amplified with transposon-specific primers and six arbitrary degenerate primers (Table 3 ) by thermal asymmetrical interlaced PCR (TAIL-PCR). The reactions were carried out with a T100 ${ }^{\mathrm{TM}}$ Thermal Cycler (Bio-Rad, USA) following the described procedure [53]. Amplified fragments were purified and sequenced. The nucleotide sequences were aligned with the complete genome sequences of E. coli strain BL21(DE3) via NCBI BLAST (http:/ / www.ncbi.nlm.nih.gov/BLAST (accessed on 20 January 2021)) to confirm the Tn5 insertion site in the mutant.

\subsection{Construction of Complementation Plasmid}

For MB12 mutant complementation, the pColdcarB plasmid was obtained as follows. The complete sequence of the carB gene was amplified from strain BL21(DE3) chromosomal DNA using primers carB-F/carB-R. After purification, the DNA fragment was cloned into the pUC18 vector to create the pUCcarB plasmid. After the integrity of the open reading frame was confirmed by sequencing, the full-length car $B$ gene was obtained using restriction endonucleases BamHI and HindIII, purified and attached to pColdII to create the expression vector pColdcarB. The plasmid pColdcarB was shifted to MB12 and picked on LB agar with $100 \mu \mathrm{g} \mathrm{mL}^{-1}$ ampicillin and $50 \mu \mathrm{g} \mathrm{mL}{ }^{-1}$ kanamycin. M12::pColdcarB was identified by PCR with primers pColdII-F/pColdII-R and BamHI/HindIII double digestion, and the correct transformant was named MB12-1. The $\operatorname{csp} A$ promoter was used to express carB in MB12-1.

\subsection{Statistical Analysis}

Data were assessed by analysis of variance using SPSS software (SPSS Inc., Chicago, IL, USA). Different letters in the figures indicate significant differences with Fisher's least significant difference test $(p \leq 0.05)$ between treatment and control.

Author Contributions: Conceptualization, Y.X., X.L. (Xiaomin Lin), H.W. and X.G.; Data curation, S.L., G.X., S.X. and X.L. (Xueting Liu); Formal analysis, G.X. and X.L. (Xueting Liu); Funding acquisition, Y.X. and H.W.; Investigation, Y.X., G.X., H.W. and X.G.; Methodology, Y.X., Shen Li and S.X.; Project administration, Y.X., H.W. and X.G.; Resources, Y.X., S.L., S.X. and X.L. (Xueting Liu); Supervision, Y.X., H.W. and X.G.; Validation, Y.X. and X.L. (Xiaomin Lin); Visualization, Y.X. and S.X.; Writing—original draft, Y.X., S.L. and G.X.; Writing—review and editing, Y.X., H.W. and X.G. All authors have read and agreed to the published version of the manuscript.

Funding: This study was financially supported by the National Key R\&D Program of China (grant 2017YFD0201101), the Natural Science Foundation of Jiangsu Province, China (grant BK20181322), the National Natural Science Foundation of China (grants 31201558 and 31972325).

Institutional Review Board Statement: Not applicable.

Informed Consent Statement: Not applicable.

Data Availability Statement: Data sharing not applicable.

Conflicts of Interest: The authors declare that they have no conflict of interest.

\section{References}

1. Huang, W.; Sun, J.; Cui, J.; Wang, G.; Kong, L.; Peng, H.; Chen, S.; Peng, D. Efficacy evaluation of fungus Syncephalastrum racemosum and nematicide avermectin against the root-knot nematode Meloidogyne incognita on cucumber. PLoS ONE 2014, 9, e89717. [CrossRef] 
2. Sikora, R.; Pocasangre, L.; zum Felde, A.; Niere, B.; Vu, T.T.; Dababat, A.A. Mutualistic endophytic fungi and in-planta suppressiveness to plant parasitic nematodes. Biol. Control. 2008, 46, 15-23. [CrossRef]

3. Nicol, J.M.; Turner, S.J.; Coyne, D.L.; Nijs, L.; Hockland, S.; Maafi, Z.T. Current nematode threats to world agriculture. In Genomics and Molecular Genetics of Plant-Nematode Interactions; Jones, J., Gheysen, G., Fenoll, C., Eds.; Springer: Dordrecht, The Netherlands, 2011; pp. 21-43.

4. Siddiqui, Z.A.; Mahmood, I. Role of bacteria in the management of plant parasitic nematodes: A review. Bioresource Technol. 1999, 69, 167-179. [CrossRef]

5. Li, J.; Zou, C.; Xu, J.; Ji, X.; Niu, X.; Yang, J.; Huang, X.; Zhang, K. Molecular mechanisms of nematode-nematophagous microbe interactions: Basis for biological control of plant-parasitic nematodes. Annu. Rev. Phytopathol. 2015, 53, 67-95. [CrossRef] [PubMed]

6. Colagiero, M.; Rosso, L.C.; Ciancio, A. Diversity and biocontrol potential of bacterial consortia associated to root-knot nematodes. Biol. Control. 2018, 120, 11-16. [CrossRef]

7. Xiang, N.; Lawrence, K.S.; Donald, P.A. Biological control potential of plant growth-promoting rhizobacteria suppression of Meloidogyne incognita on cotton and Heterodera glycines on soybean: A review. J. Phytopathol. 2018, 166, 449-458. [CrossRef]

8. Chen, Z.; Dickson, D.W.; McSorley, R.; Mitchell, D.J.; Hewlett, T.E. Suppression of Meloidogyne arenaria race 1 by soil application of endospores of Pasteuria penetrans. J. Nematol. 1996, 28, 159-168. [PubMed]

9. Kokalis-Burelle, N. Pasteuria penetrans for control of Meloidogyne incognita on tomato and cucumber, and M. arenaria on snapdragon. J. Nematol. 2015, 47, 207-213.

10. Cronin, D.; Moenne-Loccoz, Y.; Fenton, A.; Dunne, C.; Dowling, D.N.; O'gara, F. Role of 2, 4-diacetylphloroglucinol in the interactions of the biocontrol pseudomonad strain F113 with the potato cyst nematode Globodera rostochiensis. Appl. Environ. Microb. 1997, 63, 1357-1361. [CrossRef]

11. Siddiqui, I.A.; Shahid Shaukat, S. Suppression of root-knot disease by Pseudomonas fluorescens CHA0 in tomato: Importance of bacterial secondary metabolite, 2, 4-diacetylpholo- roglucinol. Soil Biol. Biochem. 2003, 35, 1615-1623. [CrossRef]

12. Niu, Q.; Huang, X.; Tian, B.; Yang, J.; Liu, J.; Zhang, L.; Zhang, K. Bacillus sp. B16 kills nematodes with a serine protease identified as a pathogenic factor. Appl. Microbiol. Biot. 2005, 69, 722-730. [CrossRef]

13. Niu, Q.; Huang, X.; Zhang, L.; Xu, J.; Yang, D.; Wei, K.; Niu, X.; An, Z.; Bennett, J.; Zou, C.; et al. A Trojan horse mechanism of bacterial pathogenesis against nematodes. Proc. Natl. Acad. Sci. USA 2010, 107, 16631-16636. [CrossRef] [PubMed]

14. Niu, Q.; Huang, X.; Zhang, L.; Li, Y.; Li, J.; Yang, J.; Zhang, K. A neutral protease from Bacillus nematocida, another potential virulence factor in the infection against nematodes. Arch. Microbiol. 2006, 185, 439-448. [CrossRef]

15. Bravo, A.; Gómez, I.; Porta, H.; García-Gómez, B.I.; Rodriguez-Almazan, C.; Pardo, L.; Soberón, M. Evolution of Bacillus thuringiensis Cry toxins insecticidal activity. Microb. Biotechnol. 2012, 6, 17-26. [CrossRef]

16. Reitz, M.; Rudolph, K.; Schroder, I.; Hoffmann-Hergarten, S.; Hallmann, J.; Sikora, R.A. Lipopolysaccharides of Rhizobium etli strain G12 act in potato roots as an inducing agent of systemic resistance to infection by the cyst nematode Globodera pallida. Appl. Environ. Microb. 2000, 66, 3515-3518. [CrossRef] [PubMed]

17. Xia, Y.; Li, S.; Liu, X.; Zhang, C.; Xu, J.; Chen, Y. Bacillus halotolerans strain LYSX1-induced systemic resistance against the root-knot nematode Meloidogyne javanica in tomato. Ann. Microbiol. 2019, 69, 1227-1233. [CrossRef]

18. Samuel, B.S.; Rowedder, H.; Braendle, C.; Félix, M.-A.; Ruvkun, G. Caenorhabditis elegans responses to bacteria from its natural habitats. Proc. Natl. Acad. Sci. USA 2016, 113, E3941-E3949. [CrossRef]

19. Anyanful, A.; Dolan-Livengood, J.M.; Lewis, T.; Sheth, S.; DeZalia, M.N.; Sherman, M.A.; Kalman, L.V.; Benian, G.M.; Kalman, D. Paralysis and killing of Caenorhabditis elegans by enteropathogenic Escherichia coli requires the bacterial tryptophanase gene. Mol. Microbiol. 2005, 57, 988-1007. [CrossRef]

20. Chou, T.-C.; Chiu, H.-C.; Kuo, C.-J.; Wu, C.-M.; Syu, W.-J.; Chiu, W.-T.; Chen, C.-S. Enterohaemorrhagic Escherichia coli O157:H7 Shiga-like toxin 1 is required for full pathogenicity and activation of the p38 mitogen-activated protein kinase pathway in Caenorhabditis elegans. Cell Microbiol. 2013, 15, 82-97. [CrossRef]

21. Maghodia, A.B.; Spiegel, Y.; Sela, S. Interactions between Escherichia coli and the plant-parasitic nematode Meloidogyne javanica. J. Appl. Microbiol. 2008, 105, 1810-1816. [CrossRef]

22. Studier, F.W.; Moffatt, B.A. Use of bacteriophage T7 RNA polymerase to direct selective high-level expression of cloned genes. J. Mol. Biol. 1986, 189, 113-130. [CrossRef]

23. Ito, M.; Kim, Y.G.; Tsuji, H.; Kiwaki, M.; Nomoto, K.; Tanaka, R.; Okada, N.; Danbara, H. A practical random mutagenesis system for probiotic Lactobacillus casei using Tn5 transposition complexes. J. Appl. Microbiol. 2010, 109, 657-666. [CrossRef] [PubMed]

24. Xia, Z.; Zhang, W.; Lei, L.; Liu, X.; Wei, H. Genome-wide investigation of the genes involved in nicotine metabolism in Pseudomonas putida J5 by Tn5 transposon mutagenesis. Appl. Microbiol. Biot. 2015, 99, 6503-6514. [CrossRef] [PubMed]

25. Zou, H.; Yuan, L.; Guo, W.; Li, Y.; Che, Y.; Zou, L.; Chen, G. Construction of a Tn5-tagged mutant library of Xanthomonas oryzae pv. oryzicola as an invaluable resource for functional genomics. Curr. Microbiol. 2011, 62, 908-916. [CrossRef] [PubMed]

26. Holden, H.M.; Thoden, J.B.; Raushel, F.M. Carbamoyl phosphate synthetase: An amazing biochemical odyssey from substrate to product. Cell Mol. Life Sci. 1999, 56, 507-522. [CrossRef]

27. Ali, N.I.; Siddiqui, I.A.; Shahid Shaukat, S.; Zaki, M.J. Nematicidal activity of some strains of Pseudomonas spp. Soil Biol. Biochem. 2002, 34, 1051-1058. [CrossRef] 
28. Mendoza, A.R.; Kiewnick, S.; Sikora, R.A. In vitro activity of Bacillus firmus against the burrowing nematode Radopholus similis, the root-knot nematode Meloidogyne incognita and the stem nematode Ditylenchus dipsaci. Biocontrol Sci. Techn. 2008, 18, 377-389. [CrossRef]

29. Xia, Y.; Xie, S.; Ma, X.; Wu, H.; Wang, X.; Gao, X. The purL gene of Bacillus subtilis is associated with nematicidal activity. FEMS Microbiol. Lett. 2011, 322, 99-107. [CrossRef]

30. Yang, X.; Wang, X.; Wang, K.; Su, L.; Li, H.; Li, R.; Shen, Q. The nematicidal effect of Camellia seed cake on root-knot nematode Meloidogyne javanica of banana. PLoS ONE 2015, 10, e0119700. [CrossRef]

31. Meyer, S.L.F.; Halbrendt, J.M.; Carta, L.K.; Skantar, A.M.; Liu, T.; Abdelnabby, H.M.E.; Vinyard, B.T. Toxicity of 2,4-diacetylphloroglucinol (DAPG) to plant-parasitic and bacterial-feeding nematodes. J. Nematol. 2009, 41, $274-280$.

32. Aballay, E.; Prodan, S.; Zamorano, A.; Castaneda-Alvarez, C. Nematicidal effect of rhizobacteria on plant-parasitic nematodes associated with vineyards. World J. Microb. Biot. 2017, 33, 131. [CrossRef] [PubMed]

33. Gao, H.; Qi, G.; Yin, R.; Zhang, H.; Li, C.; Zhao, X. Bacillus cereus strain S2 shows high nematicidal activity against Meloidogyne incognita by producing sphingosine. Sci. Rep. 2016, 6, 28756. [CrossRef]

34. Liu, Z.; Budiharjo, A.; Wang, P.; Shi, H.; Fang, J.; Borriss, R.; Zhang, K.; Huang, X. The highly modified microcin peptide plantazolicin is associated with nematicidal activity of Bacillus amyloliquefaciens FZB42. Appl. Microbiol. Biot. 2013, 97, 10081-10090. [CrossRef] [PubMed]

35. Cheng, F.; Wang, J.; Song, Z.; Cheng, J.; Zhang, D.; Liu, Y. Nematicidal effects of 5-aminolevulinic acid on plant-parasitic nematodes. J. Nematol. 2017, 49, 295-303. [CrossRef] [PubMed]

36. Xiao, T.; Tan, S.; Shen, Q.; Ran, W. Bacillus cereus X5 suppresses root-knot nematode of tomato by colonizing in roots and soil. Afr. J. Microbiol. Res. 2012, 6, 2321-2327. [CrossRef]

37. Engelbrecht, G.; Horak, I.; Jansen van Rensburg, P.J.; Claassens, S. Bacillus-based bionematicides: Development, modes of action and commercialisation. Biocontrol Sci. Techn. 2018, 28, 629-653. [CrossRef]

38. Aleshkin, G.I.; Kadzhaev, K.V.; Markov, A.P. High and low UV-dose responses in SOS-induction of the precise excision of transposons Tn1, Tn5 and Tn10 in Escherichia coli. Mutat. Res. Fund Mol. M. 1998, 401, 179-191. [CrossRef]

39. Song, X.; Guo, J.; Ma, W.; Ji, Z.; Zou, L.; Chen, G.; Zou, H. Identification of seven novel virulence genes from Xanthomonas citri subsp. citri by Tn5-based random mutagenesis. J. Microbiol. 2015, 53, 330-336. [CrossRef]

40. Kevany, B.M.; Rasko, D.A.; Thomas, M.G. Characterization of the complete zwittermicin a biosynthesis gene cluster from Bacillus cereus. Appl. Environ. Microb. 2008, 75, 1144-1155. [CrossRef]

41. Shi, D.; Caldovic, L.; Tuchman, M. Sources and fates of carbamyl phosphate: A labile energy-rich molecule with multiple facets Biology 2018, 7, 34. [CrossRef]

42. Guo, J.; Song, X.; Zou, L.; Zou, H.; Chen, G. The small and large subunits of carbamoyl- phosphate synthase exhibit diverse contributions to pathogenicity in Xanthomonas citri subsp. citri. J. Integr. Agr. 2015, 14, 1338-1347. [CrossRef]

43. Zhuo, T.; Rou, W.; Song, X.; Guo, J.; Fan, X.J.; Kamau, G.G.; Zou, H. Molecular study on the carAB operon reveals that carB gene is required for swimming and biofilm formation in Xanthomonas citri subsp. citri. Bmc Microbiol. 2015, 15, 225. [CrossRef] [PubMed]

44. Fox, B.A.; Bzik, D.J. De novo pyrimidine biosynthesis is required for virulence of Toxoplasma gondii. Nature 2002, 415, 926-929. [CrossRef]

45. Garvis, S.; Munder, A.; Ball, G.; de Bentzmann, S.; Wiehlmann, L.; Ewbank, J.J.; Tümmler, B.; Filloux, A. Caenorhabditis elegans semi-automated liquid screen reveals a specialized role for the chemotaxis gene cheB2 in Pseudomonas aeruginosa virulence. PLoS Pathog. 2009, 5, e1000540. [CrossRef] [PubMed]

46. Yorgey, P.; Rahme, L.G.; Tan, M.-W.; Ausubel, F.M. The roles of mucD and alginate in the virulence of Pseudomonas aeruginosa in plants, nematodes and mice. Mol. Microbiol. 2001, 41, 1063-1076. [CrossRef] [PubMed]

47. Geng, C.; Nie, X.; Tang, Z.; Zhang, Y.; Lin, J.; Sun, M.; Peng, D. A novel serine protease, Sep1, from Bacillus firmus DS-1 has nematicidal activity and degrades multiple intestinal-associated nematode proteins. Sci. Rep. 2016, 6, 25012. [CrossRef] [PubMed]

48. Siddiqui, I.A.; Haas, D.; Heeb, S. Extracellular protease of Pseudomonas fluorescens CHA0, a biocontrol factor with activity against the root-knot nematode Meloidogyne incognita. Appl. Environ. Microb. 2005, 71, 5646-5649. [CrossRef] [PubMed]

49. Landy, M.; Warren, G.H.; RosenmanM, S.B.; Colio, L.G. Bacillomycin: An antibiotic from Bacillus subtilis active against pathogenic fungi. Exp. Biol. Med. 1948, 67, 539-541. [CrossRef]

50. Gray, N.F. Ecology of nematophagous fungi: Comparison of the soil sprinkling method with the Baermann funnel technique in the isolation of endoparasites. Soil Biol. Biochem. 1984, 16, 81-83. [CrossRef]

51. Terefe, M.; Tefera, T.; Sakhuja, P.K. Effect of a formulation of Bacillus firmus on root-knot nematode Meloidogyne incognita infestation and the growth of tomato plants in the greenhouse and nursery. J. Invertebr. Pathol. 2009, 100, 94-99. [CrossRef]

52. Sambrook, J.; Russel, D.W. Molecular Cloning: A Laboratory Manual, 3rd ed.; Cold Spring Harbor Laboratory Press: Plainview, TX, USA, 2001; pp. 116-126.

53. Liu, Y.; Huang, N. Efficient amplification of insert end sequences from bacterial artificial chromosome clones by thermal asymmetric interlaced PCR. Plant. Mol. Biol. Rep. 1998, 16, 175. [CrossRef] 